\title{
DETERMINANTS OF RETURN'S CO-MOVEMENT FOR EFFECTIVE PORTFOLIO DIVERSIFICATION AMONG REGIONAL STOCK MARKETS 1
}

\author{
DETERMINANTES DO CO-MOVIMENTO DOS RETORNOS PARA A \\ DIVERSIFICAÇÃO EFETIVA DE PORTFÓLIOS ENTRE OS MERCADOS DE \\ AÇÕES REGIONAIS
}

Mobeen Ur Rehman ${ }^{2 *}$

PhD Scholar, Shaheed Zulfikar Ali Bhutto Institute of Science and Technology, Islamabad, Pakistan mobeenrehman@live.com

\section{Syed Muhammad Amir Shah}

Associate Professor, Allama Iqbal Open University, Islamabad, Pakistan dramirshah@aiou.edu.pk

\begin{abstract}
This paper investigates empirically the linkage between frontier and emerging markets of Asia with the developed markets of Unites States, Japan and Europe over the period of 15 years from January 2000 to December 2014. To deal with heterogeneous panels, we have made use of pooled mean group statistics suggested by Pesaran et al. (2001) for more reliable results. After testing for panel unit root and co-integration, both short and long term relationship were found among the included markets thereby supporting the feedback hypothesis. The direction of relationship is more important from developed to emerging and frontier markets than among the developing-emerging markets. Results suggest that integration is higher among EFA and Japanese markets than the EFA and US markets. These findings are in accordance with the view that level of stock market integration continues to increase. The finding of this paper has important implication for the researchers, practitioners and policy makers. Knowledge about the kind of relationship between EFA and developed markets can help governments of EFA markets to devise various strategies keeping in view their return sensitivity to the developed equity markets. This can help in predicting the return pattern of emerging and frontier markets over the period of short and long run. Furthermore, the relationship among EFA and developed markets enable investors to reap maximum diversification benefits and to minimize risks due to financial contagion or spillover phenomena.
\end{abstract}

Keywords: Heterogeneous Panels; Frontier Markets; Equity Returns; Pooled Mean Analysis. JEL Classification: G11, G15, F3, F65.

\footnotetext{
${ }^{1}$ Article received: 30/01/2016. Peer-reviewed: 29/02/2016. 2nd version received: 03/03/2016. Recommended for publication: 10/03/2016 by Luiz Felipe Pontes de Araújo Girão (Associate Editor). Published: 27/04/2016. Organization responsible for the journal: UFPB.

* This article is part of a PhD dissertation by Mobeen Ur Rehman, SZABIST, Islamabad.

${ }^{2}$ Address: Shaheed Zulfikar Ali Bhutto Institute of Science and Technology (SZABIST), H-8/4, Islamabad, Pakistan. DOI: http://dx.doi.org/10.18405/recfin20160106
} 


\section{RESUMO}

Este artigo investiga empiricamente a ligação entre a fronteira de mercados emergentes da Ásia (EFA) com os mercados desenvolvidos dos Estados Unidos, Japão e Europa durante um período de 15 anos, a partir de Janeiro de 2000 a Dezembro de 2014. Para lidar com painéis heterogêneos de dados, foi feito o uso de pooled mean group statistics, como sugerido por Pesaran et al. (2001) para se obter resultados mais confiáveis. Depois de testar a relação de curto e de longo prazos do painel de dados com testes de raiz unitária e de cointegração, encontramos relação entre os mercados analisados, apoiando assim nossa hipótese. A direção dessa relação é mais importante dos países desenvolvidos para emergentes e para os mercados de fronteira do que entre os mercados desenvolvidos e emergentes. Os resultados sugerem que a integração é maior entre o EFA e os mercados japoneses do que entre os mercados do EFA e dos EUA. Esses achados estão de acordo com a visão de que o nível de integração dos mercados de ações continua a aumentar. Essa descoberta tem implicações importantes para pesquisadores, profissionais e tomadores de decisões políticas. O conhecimento sobre o tipo de relação entre o EFA e os mercados desenvolvidos pode ajudar os governos dos países de mercados do EFA a elaborarem diversas estratégias com vistas à sua sensibilidade dos retornos em relação aos mercados de ações de países desenvolvidos. Isso pode ajudar na previsão do padrão de retornos de mercados emergentes e de fronteira ao longo dos períodos de curto e de longo prazo. Além disso, a relação entre os mercados do EFA e os desenvolvidos permite aos investidores colherem o máximo de benefícios da diversificação e minimizarem os riscos devidos ao contágio financeiro e ao fenômeno spillover.

Palavras-chave: Painéis Heterogêneos; Mercados de Fronteira; Retorno dos ativos; Pooled Mean Analysis.

\section{INTRODUCTION}

The study to investigate the presence of relationship among the developed, frontier and emerging markets has gained importance mainly because of three reasons. First, emerging markets are considered more rewarding for the international investment purposes. Secondly, these markets are sensitive to any changes in the markets of the developed world. Finally, investors can reap international diversification benefits through the regulation in these emerging and frontier stock markets by different policy makers. This can be done by making close analysis on the short and long run relation among the markets of the emerging and developed economies.

Past literature presents important methodologies regarding the investigation of relationship among the emerging and developed markets in the context of time series and country to country relationship like vector auto regression, cointegration process, granger causality test and vector error correction model proposed by Johansen (1988), Engle and Kroner BEKK-GARCH model, multivariate GARCH models proposed by Bollerslev, Engel and Wooldridge (1988) (VECHGARCH) models and standard and rolling correlation analysis. Many studies in the perspective of finding relationship covered a small panel of countries especially for emerging markets. Therefore this paper aims to cover the gaps in the previous studies by employing a novel econometric technique along with the large sample of countries over a longer period of time. Furthermore, our study has not only included emerging markets of Asia but also the frontier markets with the introduction of new terminology called EFA (Emerging and frontier markets of Asia).

We made use of the panel cointegration tests to check for the existence of long run relationship among the included markets. After the application of panel co-integration technique, we checked for the causal relationship among the selected markets by using pool mean group (PMG) estimation proposed by Pesaran et al (1999). This approach has rarely been used in finance and especially in measuring long and short run relationship among the EFA markets. By the application 
of PMG we can draw reliable results regarding the presence of short and long run relationships among the EFA and developed markets of Europe, Japan and US.

Results of our study shows that there exists a short and long term relationship among the included equity markets and reveal the presence of bidirectional causal relationship over the period of both long and short term. The variance in EFA markets due to the developed markets of Europe, Japan and US is more evident than that the reverse situation. Furthermore, the bidirectional causal relationship for the EFA markets is more with the Japanese markets than the rest of the European and US markets. In short, the panel technique that we have employed in this study was quite conclusive regarding the predictions of variance in one market due to the other. The findings of this study have important implications not only for the investors but also for the policy makers, practitioners and academicians.

This study is important for investors who want to diversify by investing in Asian neighboring countries along with the developed markets. The investigation of relationship among EFA and developed markets can have important implication for the investment community. Furthermore, this relationship can also translate in the form of increasing or decreasing market and macro-integration thereby resulting in various levels of foreign portfolio equity holding flows. A knowledge about interrelationship among EFA and developed markets can provide further insights about global financial crises, i.e. low financial integration can provide greater diversification benefits and less returns spillover. The use of pooled mean group analysis allows the analysis of short term dynamics along with the convergence in long term. This is the main differentiating aspect of this study and will have important implications for short and long term investors.

Structure of the paper is as follows. Section 2 review the past relevant literature on the topic. Section 3 introduces the econometric technique. Section 4 presents analysis of the data including the application of panel unit root and co-integration along with PMG approach to differentiate between short and long run causal linkage with the sensitivity analysis in the presence of macro-economic control variables. In the end, section 5 covers the conclusion of the study with the policy implications in light of the empirical findings.

\section{LITERATURE REVIEW}

Since the last decade, relationship among the developed and emerging markets of the world has been an important issue regarding risk minimization through portfolio diversification. Even in the crises period, spillover of returns from developed to emerging markets has been widely observed. According to Eun and Shim (1989) any kind of crises in the US market has a deep effect of the Asian and European markets. Benkato and Darrat (2003) studied the relationship among the Turkish stock exchange market with the developed markets of US, Japan and Europe over the period of 15 years and found that the movement in Turkish stock returns draw away from these developed markets in the short run but in the long run retains a balance thereby preventing ultimate breakaway. According to Harvie et al (2006), emerging markets of Singapore, Malaysia and Indonesia have significant variations on the retuns of Thailand stock market. Lee (2004) suggested that changes in US stock market also has impact on the Korean stock market. Similarly many of the past researchers like Eun and Shim (1989), Darrat and Zhong (2000), Cheung and Mak (1992) and Voronkova (2004) emphasized the influential role of developed markets on the stability of emerging markets.

Frontier and emerging markets are found to be highly integrated with developed markets. Voronkova (2004) employed Gregory-Hansen which in co-integrating relationships allow structural break. There can be many factors that can cause such co-movements like international trade, relaxation of controls on capital movement, increase in capital mobility and various alignments in policy control (Aurangzeb 2012). After the of financial crises in 2008, the spillover from the US markets to the rest of the world showed the impact that any developing markets can have on the emerging and 
developed markets (Didier et al 2010). Not only there are evidences of relationship among the developing and developed markets but also among the developed markets. Karolyi and Stulz (1996) reported significant correlation between the US and Japanese markets in times of high volatility thereby reducing the diversification benefits. Some studies like Longin and Solnik (1995) are of the view that emerging markets are less integrated due to less exposure the global factors thereby offering low sensitivity to the returns of the developed markets. According to Eun and Shim (1989) the impact of US markets among all the developed markets is greater on the emerging markets thereby retaining its position as the most influential position among the international financial markets.

Johnson and Soenen (2002) are of the opinion that the emerging and frontier markets of Asia are more integrated with the Japanese stock market. Ciarlone et al (2009) were of the view that the increase in financial integration between the developed and emerging economies can be achieved through the improvement in given emerging markets fundamentals. They also proposed that emerging markets remains highly vulnerable to the changes in the developed markets.

Yang (2006) employed DCC-GARCH methodology to examine the correlation among Japan and developing markets of Asia from 1990 to 2003 and emphasized the role of market conditions on these correlation values. Similar methodology was also used by Wang and Moore (2008) for the period of 1994-2006 during the examination of co-integration among the European developed and Central Eastern European markets with the findings that significant dynamic correlation exists among these markets. According to Aktar and Ozturk (2009), increasing level of integration among the countries is attributed to the phenomena of globalization.

Many of the past studies indicated the presence of short and long term among the financial markets According to Floros et al (2005), there exists a long term relation among the markets of Europe, Japan and US. In his study, he concluded that there exists a unidirectional causal effect between FTSE 100 to SP500 and SP500 to Nikkie 225 whereas bidirectional granger causality between Nikkie 225 to FTSE 100. Masih and Masih (1997) investigated the presence of relationship among South Asian countries of Taiwan, Singapore, South Korea and Hong Kong and US, UK and Japanese markets for the developed economies and found cointegrated vectors among them. Goh (2005) also investigated dynamic relationship among the markets of Singapore, Indonesia, Philippines, Malaysia and Thailand.

Despite of several evidences of cointegrating relationship among the developed and emerging markets, some researchers like Arhanapalli et al (1998) were unable to find any long run relationship among Asian markets using Johansen cointegration technique. According to Berger et al (2011) in his study among the frontier markets found out that lower level of integration exists between frontier and the global markets therefore offering more investment opportunities for the international investors.

Although evidences support the fact that co-movement does exist among the developed and emerging markets but the increase in such co-movements with a passage of time has been a debatable topic. Bakaert et al (2011) conducted his study on the 23 emerging and developed markets and found no increase in world co-movements but within European countries only over the period of 25 years from 1980 to 2005. According to Agenor (2005), only after the late 80's international investors started making sizable investments in the emerging markets of East Asia, Central and Eastern Europe and Pacific Basin as these market had also embarked on the significance of market regulations and reforms for attracting the foreign capital.

\section{ECONOMETRIC ANALYSIS}

We have made use of the pool mean group technique due to its ability of capturing different short run dynamics along with the identical long run relationship among heterogeneous panels. 
Pesaran et al (2001) mentioned the reasons of similar long run coefficients due to common technologies, budget constraints or arbitrage conditions that have identical effects on all the groups. For such reasons, we will consider the common coefficients of long term relationship among the included countries because of their similarity in economic and political linkages. However the short term relationships are not similar due to dynamic specification among them. Further motivation of the heterogeneity among countries over short term is due to the sensitivity that developing markets have as a result of the fluctuations in developed markets.

Like traditional models that are used to handle dynamic panel models i.e. generalized methods of moments, pooled mean group approach considers the long run relation between the variables as they can and often move in the long run ${ }^{3}$. In case of long term homogeneity among the associated variables, pooled mean group technique gives efficient and consistent long term estimators. Therefore during the application of PMG technique, the long run estimator's efficiency is broken down under the assumption of parameter homogeneity ${ }^{4}$. Furthermore, PMG application allows the variance of the short run dynamics among the associated groups as each group has its unique intrinsic characteristics. The use of traditional dynamic fixed effect technique only captures the identical short and long term dynamics as compared to pooled mean group test. With the presence of long time dimension of the under study panel, inconsistent parameter estimates can lead to conclusions that may be misleading. Pesaran et al (2001) mentioned that PMG approach has the capability to deal with long run coefficients under the homogeneous subset with the rest differing among groups. As we are dealing with the financial and economic variables in this study, this may play an important role.

The expression for the pool mean group with error correction ${ }^{5}$ is presented below.

$$
\begin{gathered}
\Delta y_{i t}=\emptyset_{i} \mu_{i, t-1}+\sum_{l=1}^{p-1} \Delta y \alpha^{\prime}{ }_{i l} \Delta y_{i, t-1}+\sum_{j=0}^{q-1} \beta^{\prime}{ }_{i j} \Delta X_{i, t-j}+\gamma_{i}^{\prime} z_{i t}^{\prime}+\mu_{i}^{\prime} v_{i t}^{\prime}+\epsilon_{i t} \\
\mu_{\mathrm{i}, \mathrm{t}-1}=\mathrm{y}_{\mathrm{i}, \mathrm{t}-1}-\emptyset^{\prime} \mathrm{X}_{\mathrm{it}}
\end{gathered}
$$

In the above equation, $\mathrm{y}_{\mathrm{it}}$ is the dependent variable whereas $\mathrm{X}_{\mathrm{it}}$ represents independent variables having long run and short run effect on the dependent variable. $Z_{i t}$ can have a long run variance on the dependent variable, $\epsilon_{i t}$ represents error term and $v_{i t}$ are the regressors with deterministic vectors like time trend, constant and dummy variables. $\emptyset_{i}$ represents the short run error correction coefficient providing convergence to the long run equilibrium whereas $\mu_{\mathrm{i}, \mathrm{t}-1}$ shows the deviation from the long run. $\theta$ represents vector of long run common coefficient measuring impact on the dependent variable due to each of the vector in variable $X_{i t} . \alpha, \beta$ and $\gamma$ are the coefficient vectors measuring the short run responses on the corresponding variables due to $\Delta \mathrm{y}_{\mathrm{it}}$. Country specific effects are represented by $\mu_{\mathrm{i}}$. Schwarz Bayesian criteria has been employed for the selection of lag order $\mathrm{p}$ and $\mathrm{q}$. According to Pesaran et al (2001), maximum likelihood estimators have consistent values with normal distribution. The pool mean group framework is commonly known to be used for macro-economic variables but rarely for the financial variables. In this study we have applied this technique to check for the short and long run relationship among EFA and developed markets with the inclusion of couple of macro-economic variables at the later stage.

\footnotetext{
${ }^{3}$ For further reading, refer to Arellano and Bover (1995).

${ }^{4}$ According to Pesaran et al. (2001), MG estimation takes average of the individual regression estimates over the period of long and short run.

${ }^{5}$ Autoregressive distributed lag model can be consulted for further insights if error correction model.
} 


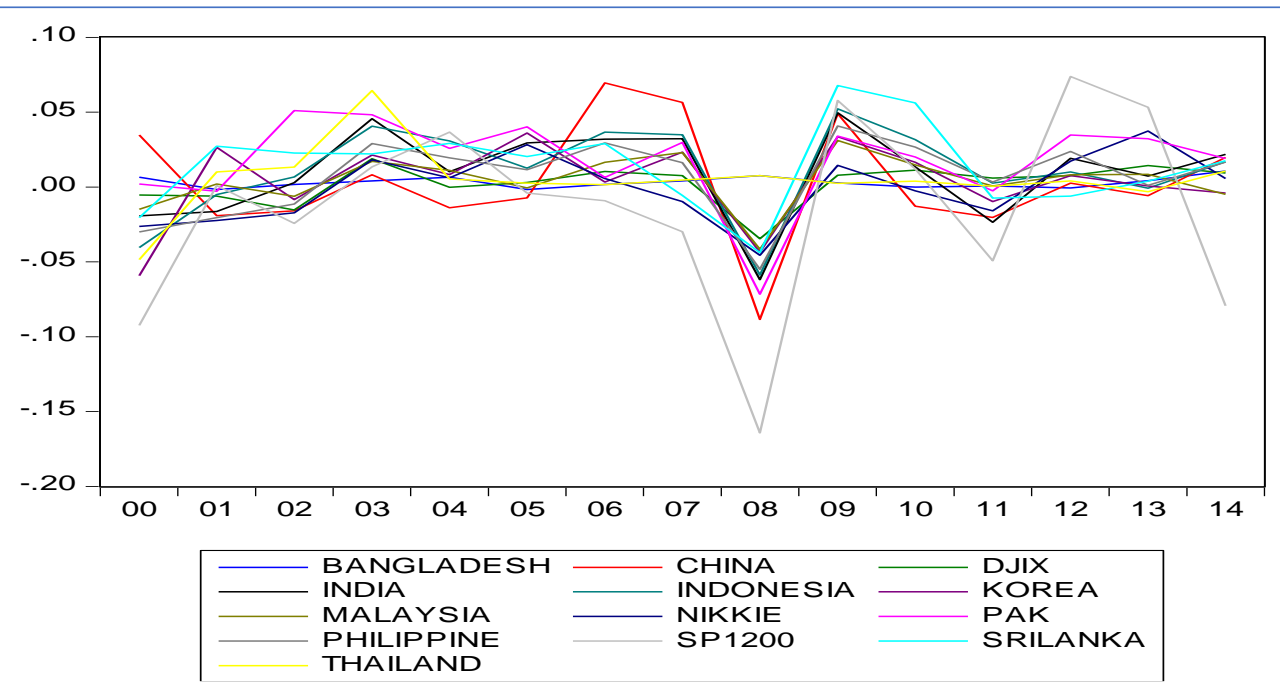

\section{ANALYSIS AND DISCUSSION}

In this paper the interrelationship among the EFA stock markets (Pakistan, India, Bangladesh, China, Srilanka, Indonesia, Thailand, Malaysia, Korea and Philippine), SP1200, DJ Stoxx Europe and Nikkie stock exchange is investigated over the period of short and long run. For comparison of developing markets with the developed ones, we have taken broader exchange of SP1200. Similarly, for comparison with Europe, we have taken DJ Stoxx along with the Japanese Nikkie 225 index. Reason for selecting the DJ stoxx is that it incorporates major Western European markets like Austria, Denmark, France, Greece, Ireland, Luxembourg, Norway, Spain, Switzerland, Belgium, Finland, Germany, Iceland, Italy, Netherlands, Portugal, Sweden and the United Kingdom. We have taken data for all the included countries from January 2000 to December 2014. The included period is quite sufficient to incorporate and consider all the major economic and financial events so that the short and long run relationship among the included markets within the panel can be accurately estimated. Data on all the stock market indices is on monthly basis and is taken from yahoo finance and Econstat website.

\subsection{Preliminary Analysis of the Data}

The depiction of all the time series variables in figure 1 captures their joint dynamics following same patterns and time trend with the presence of long run relationship. During the financial crises of 2008, all of the markets showed a decline in returns that motivates us to find out the underlying relationship of both long and short run in the presence of certain events and conditions.

In table 1 return characteristics of all the included market indices are presented to have a closer look at the descriptive and statistical properties. For EFA markets average return values ranges between the lowest of Bangladesh and Korea i.e. 0.3 percent and the highest pf Pakistan i.e. 1.8 percent. Among the developed markets, DJ stoxx returns have the maximum return value of 0.2 percent. As far as the risk for investor is concerned, Pakistan has the maximum value whereas Bangladesh has minimum value of it i.e. 2.2 percent. In terms of risk, developed markets offer safer investment (i.e. low variance) opportunities than their EFA counterparts. Error variance among the included groups in the pool mean framework is supported by the fact that risk factor represented by the standard deviation varies across each of the country. Coefficient of skewness is negative for all the markets except Bangladesh and Srilanka whereas kurtosis coefficient is less than three for all the developed markets and majority of the EFA markets. ARCH effect is present in all of the equity markets whereas only KSE100 index of Pakistan has the JB statistic rejecting normality hypothesis. 
In correlation analysis, all the developed markets are significantly correlated with the EFA markets. Indian market has the highest correlation value with Nikkie 225 index along with the normal correlation values among EFA and developed markets. It can also be seen that Nikkie 225 index as compared to the SP1200 and DJ stoxx indices is more correlated with the EFA countries. Correlation among the developed markets has moderate value and so among the EFA countries excluding Indian stock market.

The statistics presented above gives us an indication of the relationship among the included developed and EFA markets but more sophisticated techniques like panel cointegration and PMG will enable us to have a much clearer and better understanding of the short and long run dynamics.

Table 1

Descriptive, Statistical and Correlation properties among the return series.

\begin{tabular}{|c|c|c|c|c|c|c|c|c|c|c|c|c|c|}
\hline \multirow[b]{2}{*}{ Variables } & \multirow[b]{2}{*}{ Pak } & \multirow[b]{2}{*}{ India } & \multirow[b]{2}{*}{$\begin{array}{c}\text { Bangla- } \\
\text { desh }\end{array}$} & \multirow[b]{2}{*}{ China } & \multirow[b]{2}{*}{$\begin{array}{c}\text { Sri- } \\
\text { lanka }\end{array}$} & \multirow[b]{2}{*}{$\begin{array}{l}\text { Indo- } \\
\text { nesia }\end{array}$} & \multirow[b]{2}{*}{ Korea } & \multirow[b]{2}{*}{$\begin{array}{c}\text { Ma- } \\
\text { laysia }\end{array}$} & \multirow[b]{2}{*}{$\begin{array}{l}\text { Phi- } \\
\text { lippine }\end{array}$} & \multicolumn{2}{|r|}{ DJ } & \multirow[b]{2}{*}{$\begin{array}{c}\text { Nikkie } \\
225\end{array}$} & \multirow[b]{2}{*}{$\begin{array}{l}\text { S\&P } \\
1200\end{array}$} \\
\hline & & & & & & & & & & $\begin{array}{l}\text { Thai- } \\
\text { land }\end{array}$ & $\begin{array}{c}\text { Stoxx } \\
600\end{array}$ & & \\
\hline Mean & 0.018 & 0.009 & 0.003 & 0.004 & 0.014 & 0.011 & 0.003 & 0.004 & 0.007 & 0.005 & 0.002 & 0.000 & -0.014 \\
\hline Max. & 0.267 & 0.249 & 0.101 & 0.243 & 0.225 & 0.183 & 0.203 & 0.127 & 0.154 & 0.212 & 0.101 & 0.121 & 0.309 \\
\hline Min. & -0.448 & -0.273 & -0.098 & -0.283 & -0.176 & -0.377 & -0.263 & -0.165 & -0.275 & -0.244 & -0.152 & -0.272 & -0.667 \\
\hline Std. dev. & 0.083 & 0.071 & 0.022 & 0.078 & 0.071 & 0.069 & 0.069 & 0.045 & 0.063 & 0.050 & 0.042 & 0.058 & 0.144 \\
\hline Skew. & -1.500 & -0.508 & 0.253 & -0.548 & 0.271 & -1.130 & -0.428 & -0.423 & -0.690 & -0.659 & -0.689 & -0.757 & -0.795 \\
\hline Kurt. & 6.701 & 1.457 & 7.180 & 1.627 & 0.665 & 4.679 & 1.036 & 1.385 & 1.903 & 7.624 & 1.222 & 1.629 & 2.195 \\
\hline $\mathrm{ARCH}$ & $46.22^{*}$ & $23.60^{* *}$ & $180.0^{*}$ & $30.82^{*}$ & $38.42^{*}$ & $42.96^{*}$ & $42.12^{*}$ & $26.83^{*}$ & $41.21^{*}$ & 19.28 & $25.46^{* *}$ & $66.98^{*}$ & $66.91^{*}$ \\
\hline $\mathrm{JB}$ & $404.32^{*}$ & $0.293^{*}$ & $0.823^{*}$ & $0.503^{*}$ & $5.547^{*}$ & $1.800^{*}$ & $1.616^{*}$ & $0.961^{*}$ & $0.203^{*}$ & $3.398^{*}$ & $0.471^{*}$ & $3.279^{*}$ & $2.783^{*}$ \\
\hline \multicolumn{14}{|l|}{ Correlations } \\
\hline Pak & 1 & 0.200 & 0.017 & 0.098 & 0.104 & 0.144 & 0.213 & 0.235 & 0.135 & 0.132 & 0.187 & 0.206 & 0.110 \\
\hline India & & 1 & -0.023 & 0.340 & 0.233 & 0.629 & 0.628 & 0.497 & 0.542 & 0.288 & 0.226 & 0.573 & 0.294 \\
\hline Bangladesh & & & 1 & -0.029 & -0.068 & -0.061 & -0.049 & -0.019 & -0.041 & -0.079 & 0.088 & -0.050 & -0.044 \\
\hline China & & & & 1 & 0.035 & 0.249 & 0.284 & 0.342 & 0.218 & -0.024 & -0.038 & 0.294 & 0.086 \\
\hline Srilanka & & & & & 1 & 0.243 & 0.202 & 0.172 & 0.199 & 0.022 & 0.159 & 0.208 & 0.149 \\
\hline Indonesia & & & & & & 1 & 0.562 & 0.500 & 0.642 & 0.290 & 0.190 & 0.481 & 0.260 \\
\hline Korea & & & & & & & 1 & 0.406 & 0.514 & 0.403 & 0.309 & 0.562 & 0.292 \\
\hline Malaysia & & & & & & & & 1 & 0.368 & 0.203 & 0.217 & 0.337 & 0.339 \\
\hline Philippine & & & & & & & & & 1 & 0.442 & 0.234 & 0.387 & 0.246 \\
\hline Thailand & & & & & & & & & & 1 & 0.294 & 0.202 & 0.146 \\
\hline \multicolumn{14}{|l|}{ DJ Stoxx } \\
\hline Europe 600 & & & & & & & & & & & 1 & 0.243 & 0.215 \\
\hline Nikkie 225 & & & & & & & & & & & & 1 & 0.313 \\
\hline S\&P1200 & & & & & & & & & & & & & 1 \\
\hline
\end{tabular}

Notes: * represents the rejection of null hypothesis at 1 percent, ${ }^{* *}$ at 5 percent and ${ }^{* * *}$ at 10 percent. Values in bold are different from 0 with a significance level alpha $=0.05$. JB is the Jarque bera normality test. LB is the test for autocorrelation and represents Ljung-Box of order 12. Conditional heteroscedasticity is represented by $\mathrm{ARCH}$ values of order 12. Bold values in correlation table indicates the significance level.

\subsection{Panel Unit Root Test}

Before the application of panel cointegration test, we have applied panel unit root on our stock market indices to check for the stationarity issue. Levin, Lin and Chu (2002) and Im, Pesaran and Shin (1997) tests are used with the results indicating stationary results at level for EFA and developed markets. The power of the Levin-Lin-Chu is its probability of rejecting null hypothesis if false where null hypothesis is the presence of unit root. The expression of Augmented Dickey Fuller test for cross section groups is given below.

$$
\Delta y_{i t}-\rho_{i} y_{i, t-1}+\sum_{L=1}^{p i} \theta i L \Delta y_{i t-\mathrm{L}}+\alpha_{m i} d_{m t}+\varepsilon_{i t}
$$


After running the above equation and obtaining residuals $\Delta y_{i t}$ and $\Delta y_{i, t-L}$, we standardized the residuals. In the final stage, we ran pooled OLS regression expression of which is presented below.

$$
\hat{e}_{i t}-\rho \hat{v}_{i, t-1}+\bar{\epsilon}_{i t}
$$

Along with the application of LLC statistic, we have made use of the IPS statistic as our panel data is balanced. Both the test statistics presents almost identical results suggesting stationary at level.

Table 2

Panel Unit Root Analysis

\begin{tabular}{lllll}
\hline \multirow{2}{*}{ Series } & \multicolumn{2}{c}{ Levin, Lin \& Chu } & \multicolumn{2}{c}{ Im, Pesaran and Shin } \\
& Statistic & Prob. & Statistics & Prob. \\
\hline EFA & $-0.89026^{*}$ & 0.0017 & $-38.006^{*}$ & 0.0000 \\
SP1200 & $-0.78614^{*}$ & 0.0189 & $-11.766^{*}$ & 0.0000 \\
DJ Stoxx & $-0.98268^{*}$ & 0.0017 & $-12.551^{*}$ & 0.0000 \\
Nikkie 225 & $-0.85313^{*}$ & 0.0032 & $-18.203^{*}$ & 0.0000 \\
\hline
\end{tabular}

Notes: ${ }^{*}$ represents the rejection of null hypothesis at 1 percent, ${ }^{* *}$ at 5 percent and ${ }^{* * *}$ at 10 percent.

\subsection{Panel Cointegration Test}

To check the long term dependence among the included variables, we applied Pedroni (2004) ${ }^{6}$ cointegration statistic, mathematical expression of which is presented below.

$$
y_{i t=} \delta_{1 i}+\delta_{2 i} t+\theta_{1 i} X_{1, i t}+\theta_{2 i} X_{2, i t}+\theta_{3 i} X_{3, i t} \epsilon_{i t}
$$

We tried to check the cointegration in every possible case as the direction of the linkages is not known to us. Thereby any variable can play an important role of a forcing variable. For that particular reason, we have run four models with the change in dependent variable each time. In model $1, y_{i t}$ is EFA whereas $X_{1, i t}$ is DJ stoxx, $X_{2, i t}$ is SP1200 and $X_{3, i t}$ is Nikkie index. In model 2, $y_{i t}$ is DJ stoxx, $X_{1, i t}$ is SP1200, $X_{2, i t}$ is Nikkie whereas $X_{3, i t}$ represents EFA markets. In model 3, $y_{i t}$ is SP1200 whereas $X_{1, i t}$ is Nikkie, $X_{2, i t}$ is EFA markets and $X_{3, i t}$ is DJ stoxx. In model $4, y_{i t}$ is Nikkie index, $X_{1, i t}$ is EFA markets, $X_{2, i t}$ is DJ stoxx and $X_{3, i t}$ is Nikkie index.

Table 3

\begin{tabular}{|c|c|c|}
\hline Model & Rho Statistics (Panel) & Rho Statistics (Group) \\
\hline \multirow[t]{2}{*}{ Model 1} & $-53.79^{*}$ & -57.97 \\
\hline & $(-34.5)$ & $(-43.08)$ \\
\hline \multirow[t]{2}{*}{ Model 2} & $-57.76^{*}$ & $-62.33^{*}$ \\
\hline & $(-36.03)$ & $(-44.4)$ \\
\hline \multirow[t]{2}{*}{ Model 3} & $-55.34^{*}$ & $-59.69^{*}$ \\
\hline & $(-37.24)$ & $(-45.76)$ \\
\hline \multirow[t]{2}{*}{ Model 4} & $-54.84^{*}$ & $-59.12^{*}$ \\
\hline & $(-37.13)$ & $(-45.61)$ \\
\hline
\end{tabular}

Panel Cointegration Analysis

Notes: ${ }^{*}$ represents the rejection of null hypothesis of no co-integration among the series. Values in parenthesis represents $t$ values.

\footnotetext{
${ }^{6}$ Two statistics that we have used in this paper are panel rho statistics for homogeneity among the groups and group rho
} statistic used for the heterogeneity among groups. 
Results of our panel cointegration test for long run relationships are presented in table 3. It is evident from the results that all the markets of EFA along with the developed markets are integrated with each other. These finding should be considered by the international investors because of having the common trend among returns. According to Madaleno and Pinho (2010), existing relationship among the emerging and developed equity markets may change during a crises period therefore despite of common trends in returns, risks can emerge.

\section{DISCUSSION}

After running the cointegration tests on our selected markets, we will find out the causal linkage among SP1200, Nikkie225, DJ stoxx and EFA markets on the basis of PMG framework presented in eq. (1). We have tested four models in which $y_{i t}$ represents EFA markets as a dependent variable in model 1, DJIX in model 2, Nikkie225 in model 3 whereas SP1200 in model 4 . All of the remaining variables are contained in each model as independent variables contained in $X_{i t}$. We have not included any control variables in the model and variables in the $X_{i t}$ vectors are tested only. Statistical significance of our model will test the presence of short and long run causal linkage among these markets.

Table 4

Pool Mean Group (Long run estimates)

\begin{tabular}{|c|c|c|c|c|c|}
\hline & & \multicolumn{4}{|c|}{ Dependent Variables } \\
\hline & & EFA & DJIX & Nikkie & SP1200 \\
\hline \multirow[t]{4}{*}{ Independent Variables } & EFA & - & $\begin{array}{l}0.1250^{*} \\
(0.0228)\end{array}$ & $\begin{array}{l}0.2515^{*} \\
(0.0277)\end{array}$ & $\begin{array}{c}0.1326^{*} \\
(0.0815)\end{array}$ \\
\hline & DJIX & $\begin{array}{c}0.1612^{*} \\
(0.0472)\end{array}$ & - & $\begin{array}{c}0.5321^{*} \\
(0.0425)\end{array}$ & $\begin{array}{c}0.4157^{*} \\
(0.1220)\end{array}$ \\
\hline & Nikkie & $\begin{array}{l}0.2304^{*} \\
(0.0364)\end{array}$ & $\begin{array}{c}0.0858^{*} \\
(0.0265)\end{array}$ & 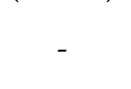 & $\begin{array}{c}0.9758^{*} \\
(0.0912)\end{array}$ \\
\hline & SP1200 & $\begin{array}{c}0.0523^{*} \\
(0.0136)\end{array}$ & $\begin{array}{l}0.0353^{*} \\
(0.0099)\end{array}$ & $\begin{array}{l}0.0886^{*} \\
(0.0119)\end{array}$ & - \\
\hline
\end{tabular}

Notes: ${ }^{*}$ represents significance level at 1 percent, ${ }^{* *}$ at 5 percent and ${ }^{* * *}$ at 10 percent. Values in parenthesis represents standard error of the respective variables

By examining the results presented in table 4, long run relationship among all the included indices is evident showing sensitivity of each market to the others. Considering the first model, Nikkie stock market produces maximum variance of 23 percent in EFA markets whereas SP1200 produces variation of 5.23 percent. Considering rest of the models, except for Nikkie market, all indices produces an optimal variation in their panel counterparts implying that the exogeneous variables have more variations than the dependent variables. Another very important finding that can be extracted from the above analysis is that all the coefficient values are positive. This means that impact of the long run causal relationship is more important for investors than the direction of relationship.

Table 5

Pool Mean Group (Short run estimates)

\begin{tabular}{|c|c|c|c|c|c|}
\hline & & \multicolumn{4}{|c|}{ Independent Variables } \\
\hline & & EFA & DJIX & Nikkie & SP1200 \\
\hline \multirow[t]{4}{*}{ Dependent Variables } & EFA & - & $\begin{array}{l}0.0864^{*} \\
(0.0236)\end{array}$ & $\begin{array}{l}0.2180^{*} \\
(0.0278)\end{array}$ & $\begin{array}{l}0.1766^{*} \\
(0.0612)\end{array}$ \\
\hline & DJIX & $\begin{array}{c}0.1046^{*} \\
(0.0445)\end{array}$ & 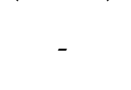 & $\begin{array}{l}0.1952^{*} \\
(0.0108)\end{array}$ & $\begin{array}{l}0.4702 * \\
(0.0173)\end{array}$ \\
\hline & Nikkie & $\begin{array}{l}0.2746^{*} \\
(0.0453)\end{array}$ & $\begin{array}{c}0.1278^{*} \\
(0.0048)\end{array}$ & - & $\begin{array}{l}0.5237^{*} \\
(0.0160)\end{array}$ \\
\hline & SP1200 & $\begin{array}{l}0.0329^{*} \\
(0.0033)\end{array}$ & $\begin{array}{l}0.0435^{*} \\
(0.0004)\end{array}$ & $\begin{array}{l}0.0750^{*} \\
(0.0025)\end{array}$ & - \\
\hline
\end{tabular}

Notes: ${ }^{*}$ represents significance level at 1 percent, ${ }^{* *}$ at 5 percent and ${ }^{* *}$ at 10 percent. Values in parenthesis represents standard error of the respective variables 
Results of table 5 highlight the fact that all the long run causal relationship among the included stock market induces are driven by the short run adjustment in remaining variables. By having a look at the table presented above, we can see that again Nikkie 225 index produces maximum significance variation in the EFA markets whereas moderate changes are induces by the SP1200 and DJ stoxx index. For the remaining models, Nikkie and DJ stoxx produces significance variations in the SP1200 index returns. It means that the long term relationship among these markets is also driven by the variations produced in short run thereby converging to the equilibrium position in the long run. It is also important to highlight that the magnitude of variance is significant and positive in short run but lower than the long run.

Another finding is that the variance of the forcing variables on dependent variables in each of the model is not equally sensitive. Variations produced by the developed markets in EFA markets are more than the reverse situation. Furthermore, more changes are induced by Japanese and US markets in EFA markets than the European markets. These findings are also reinforced by our findings of return correlation presented in table 1 . However if we take a look at the relation among developed markets, it can be seen that changes in the US markets have a dominant effect on the European and Japanese markets. Similar findings are also reported by Boubaker and Jouini (2014) during their work on the return relation of emerging markets and Yanget et al (2003) who also documented a strong influence of US markets on the emerging market returns.

Final results of the pool mean group statistics reveal that the both short and long run relationship are consistent with our preliminary findings of unconditional correlation among the included equity indices result presented in table 1. Common trend among all the included markets is quite evident along with the significant correlation results thereby implying the presence of long run relationship and the variance of the dependent variable due to the fluctuation in other forcing variables in the model.

\section{ROBUSTNESS TEST}

To check the robustness of the bidirectional causal short and long run relationship among the selected markets, we have carried out the sensitivity analysis. We have introduced exchange rate and Brent oil prices as a control variables to check the short and long run dynamics among the developed and EFA markets. $\mathrm{Z}_{\text {it }}^{\prime}$ in equation 1 represents the variables of the vectors along with the auxiliary variables i.e. exchange rate and the Brent oil prices.

Table 6

Pool Mean Group (Long run estimates)

\begin{tabular}{|c|c|c|c|c|c|}
\hline & & \multicolumn{4}{|c|}{ Dependent Variables } \\
\hline & & EFA & DJIX & Nikkie & SP1200 \\
\hline \multirow[t]{6}{*}{ Independent Variables } & EFA & 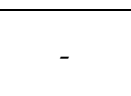 & $\begin{array}{l}0.1324^{*} \\
(0.0236)\end{array}$ & $\begin{array}{l}0.2518^{*} \\
(0.0282)\end{array}$ & $\begin{array}{c}0.1031 \\
(0.0914)\end{array}$ \\
\hline & DJIX & $\begin{array}{c}0.1495^{*} \\
(0.0439)\end{array}$ & ( & $\begin{array}{l}0.4912^{*} \\
(0.0416)\end{array}$ & $\begin{array}{l}0.3990^{*} \\
(0.0178)\end{array}$ \\
\hline & Nikkie & $\begin{array}{l}0.2158^{*} \\
(0.0343)\end{array}$ & $\begin{array}{l}0.0599^{* *} \\
(0.0270)\end{array}$ & - & $\begin{array}{l}0.8499^{*} \\
(0.0160)\end{array}$ \\
\hline & SP1200 & $\begin{array}{l}0.0461^{*} \\
(0.0129)\end{array}$ & $\begin{array}{l}0.0289^{*} \\
(0.0100)\end{array}$ & $\begin{array}{l}0.0675^{*} \\
(0.0119)\end{array}$ & - \\
\hline & Exchange Rate & $\begin{array}{l}-0.0008^{*} \\
(0.0002)\end{array}$ & $\begin{array}{c}-0.0003^{* *} \\
(0.0002)\end{array}$ & $\begin{array}{c}0.0001 \\
(0.0002)\end{array}$ & $\begin{array}{c}0.0007 \\
(0.0001)\end{array}$ \\
\hline & Brent Oil & $\begin{array}{l}-0.0003^{*} \\
(0.0001)\end{array}$ & $\begin{array}{l}-0.0000 \\
(0.0001)\end{array}$ & $\begin{array}{l}0.0002^{* *} \\
(0.0001)\end{array}$ & $\begin{array}{c}0.0004 \\
(0.0001)\end{array}$ \\
\hline
\end{tabular}

Notes: ${ }^{*}$ represents significance level at 1 percent, ${ }^{* *}$ at 5 percent and ${ }^{* * *}$ at 10 percent. Values in parenthesis represents standard error of the respective variables 
Table 6 and 7 shows the short and long run relation among the selected developed and EFA markets in the presence of control variables. It can be seen that both short and long run bidirectional causal links exist among these markets. All the signs before and after the inclusion of control variables remain the same. Among the developed markets, low coefficient values indicate moderate relationship among them whereas EFA markets are sensitive to the changes in European markets both over the short and long run periods. Exchange rate and Brent oil prices have mild negative coefficients towards European and EFA markets whereas positive towards Japanese and US markets over the period of long run. In short run exchange rate has mid positive values in all of the markets whereas Brent oil prices have weak negative coefficient values.

Table 7

Pool Mean Group (Short run estimates)

\begin{tabular}{|c|c|c|c|c|c|}
\hline & & \multicolumn{4}{|c|}{ Dependent Variables } \\
\hline & & EFA & DJIX & Nikkie & SP1200 \\
\hline \multirow[t]{6}{*}{ Independent Variables } & EFA & - & $\begin{array}{l}0.0883^{*} \\
(0.0237)\end{array}$ & $\begin{array}{c}0.2154^{*} \\
(0.0276)\end{array}$ & $\begin{array}{l}0.1607^{*} \\
(0.0161)\end{array}$ \\
\hline & DJIX & $\begin{array}{l}0.1034^{*} \\
(0.0436)\end{array}$ & - & $\begin{array}{c}0.1696^{*} \\
(0.0107)\end{array}$ & $\begin{array}{c}0.4419^{*} \\
(0.0178)\end{array}$ \\
\hline & Nikkie & $\begin{array}{l}0.2676^{*} \\
(0.0429)\end{array}$ & $\begin{array}{l}0.1133^{*} \\
(0.0050)\end{array}$ & 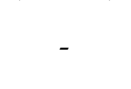 & $\begin{array}{l}0.4639 * \\
(0.0160)\end{array}$ \\
\hline & SP1200 & $\begin{array}{l}0.0310^{*} \\
(0.0031)\end{array}$ & $\begin{array}{l}0.0410^{*} \\
(0.0005)\end{array}$ & $\begin{array}{c}0.0660^{*} \\
(0.0023)\end{array}$ & - \\
\hline & Exchange Rate & $\begin{array}{c}0.0036^{*} \\
(0.0013)\end{array}$ & $\begin{array}{l}-0.0005^{*} \\
(0.0002)\end{array}$ & $\begin{array}{l}-0.0005 \\
(0.0003)\end{array}$ & $\begin{array}{c}0.0024^{*} \\
(0.0001)\end{array}$ \\
\hline & Brent Oil & $\begin{array}{l}-0.0004 \\
(0.0003)\end{array}$ & $\begin{array}{l}-0.0005^{*} \\
(0.0001)\end{array}$ & $\begin{array}{l}-0.0014^{*} \\
(0.0001)\end{array}$ & $\begin{array}{l}-0.0030 * \\
(0.0001)\end{array}$ \\
\hline
\end{tabular}

Notes: ${ }^{*}$ represents significance level at 1 percent, ${ }^{* *}$ at 5 percent and ${ }^{* *}$ at 10 percent. Values in parenthesis represents standard error of the respective variables

\section{CONCLUSION}

Although lot of work has been done among the Asian emerging and Developed markets but very few have discussed the existing relationship in panel framework. To deal with dynamic heterogeneous panels, we have adopted pool mean group technique to check the short and long run relation among them. We have tested the bidirectional causal relationship over the span of 15 years among major developed and emerging and frontier markets of Asia (EFA). Our study confirms strong relation among these markets with mild relation among the developed markets in both short and long run before and after the inclusion of exchange rate and Brent oil prices as control variables.

Our findings of the relationship among all these EFA and developed markets like US, Europe and Japan can be of great interest to policy makers, practitioners and academicians. Based on the bidirectional causal relationship of the EFA markets with the developed markets, governments of EFA markets can devise various strategies keeping in view their return sensitivity to the developed equities. This can also help in predicting the returns pattern of emerging and frontier markets over the period of short and long run.

Investors interested in international investments have strong implications regarding the short and long run relationship among these associated markets as the magnitude and signs of casual relationship can play important role. These established relationship among the EFA and developed markets enable investors to reap maximum diversification benefits and to minimize respective risks due to financial contagion or spillover phenomena.

Future research avenues based on this study are to explore the factors responsible for such short and long run causal relationships among developed and EFA markets. Global factors identifi- 
cation can also be of utmost importance while exploring the causes of such interrelationships. Existence of relationship among the EFA and developed markets can be further examined to determine whether the relationship among them is consensual or not. It can also be helpful to for investors to investigate the extent of volatility transmission among these associated markets from the perspective of the sector as the level of variations can have varying coefficients influenced by such factors. The underlying rationale is that at the national level, stock prices can hide such characteristics specific to sectors and each sector reacts differently to different sectors.

\section{ACKNOWLEDGEMENT}

The author is grateful to the anonymous referees of the journal for their extremely useful suggestions to improve the quality of the paper.

\section{REFERENCES}

Arshanapalli, B. G., Coggin, T. D., \& Doukas, J. (1998). Multifactor asset pricing analysis of international value investment strategies. The Journal of Portfolio Management, 24(4), 10-23.

Agénor, P. R. (2005). The analytics of segmented labor markets. Centre for Growth and Business Cycle Research Discussion Paper Series, 52Aktar, I., \& Ozturk, L. (2009). Can unemployment be cured by economic growth and foreign direct investment in Turkey. International Research Journal of Finance and Economics, 27, 203-211.

Bekaert, G., Harvey, C. R., \& Lundblad, C. (2011). Financial openness and productivity. World Development, 39(1), 1-19.

Bekaert, G., Harvey, C. R., \& Lundblad, C. (2006). Growth volatility and financial liberalization. Journal of International Money and Finance, 25(3), 370-403.

Benkato, O. M. (2003). Interdependence and volatility spillovers under market liberalization: the case of Istanbul Stock Exchange. Journal of Business Finance \& Accounting, 30(7-8), 1089-1114.

Berger, D., Pukthuanthong, K., \& Yang, J. J. (2011). International diversification with frontier markets. Journal of Financial Economics, 101(1), 227-242.

Cheung, Y. L., \& Mak, S. C. (1992). The international transmission of stock market fluctuation between the developed markets and the Asian-Pacific markets. Applied Financial Economics, 2(1), 43-47.

Ciarlone, A., Piselli, P., \& Trebeschi, G. (2009). Emerging markets' spreads and global financial conditions. Journal of International Financial Markets, Institutions and Money, 19(2), 222-239.

Darrat, A. F., \& Darrat, A. F., \& Zhong, M. (2000). On Testing the Random-Walk Hypothesis: A Model-Comparison Approach. Financial Review, 35(3), 105-124.

Didier, T., Love, I., \& Martinez Peria, M. S. (2010). What explains stock markets' vulnerability to the 2007-2008 crisis? World Bank Policy Research Working Paper Series.

Eun, C. S., \& Shim, S. (1989). International transmission of stock market movements. Journal of Financial and Quantitative Analysis, 24(02), 241-256. 
Floros, C. (2005). Price linkages between the US, Japan and UK stock markets. Financial Markets and Portfolio Management, 19(2), 169-178.

Goh, B. H. (2005). The dynamic effects of the Asian financial crisis on construction demand and tender price levels in Singapore. Building and Environment, 40(2), 267-276.

Johnson, R., \& Soenen, L. (2002). Asian economic integration and stock market comovement. Journal of Financial Research, 25(1), 141-157.

Karolyi, G. A., \& Stulz, R. M. (1996). Why do markets move together? An investigation of US-Japan stock return comovements. The Journal of Finance, 51(3), 951-986.

Longin, F., \& Solnik, B. (1995). Is the correlation in international equity returns constant: 1960-1990? Journal of International Money and Finance, 14(1), 3-26.

Mahmood, Y., Bokhari, R., \& Aslam, M. (2013). Trade-off between Inflation, Interest and Unemployment Rate of Pakistan: A Cointegration Analysis. Pakistan Journal of Commerce and Social Sciences, 7(3), 482-492.

Masih, A. M., \& Masih, R. (1997). Dynamic linkages and the propagation mechanism driving major international stock markets: an analysis of the pre-and post-crash eras. The Quarterly Review of Economics and Finance, 37(4), 859-885.

Shik Lee, H. (2004). International transmission of stock market movements: a wavelet analysis. Applied Economics Letters, 11(3), 197-201.

Voronkova, S. (2004). Equity market integration in Central European emerging markets: A cointegration analysis with shifting regimes. International Review of Financial Analysis, 13(5), 633-647.

Wang, P., \& Moore, T. (2008). Stock Market Integration for the Transition Economies: Time-varying conditional correlation approach. The Manchester School, 76(s1), 116-133.

Yang, Y. (2006). China's Integration into the World Economy: implications for developing countries. Asian-Pacific Economic Literature, 20(1), 40-56. 